\title{
Peran Parenting Self-Efficacy dan Optimisme terhadap Psychological Well-Being Ibu yang Memiliki Anak Intellectual Disability
}

\author{
Nuri Ersy Pasyola, Asti Meiza Abdullah, Diah Puspasari \\ Fakultas Psikologi, Univesitas Islam Negeri Sunan Gunung Djati Bandung, Indonesia \\ e-mail: diah.puspasari@uinsgd.ac.id
}

\begin{abstract}
The presence of children will affect the lives of their parents. Parenting and educating Intellectual Disability (ID) children creates certain pressures, especially for mothers. Many mothers experienced stress and have feelings of uncertainty about their ability to care for which lead to pessimism. These stress and anxiety may have an impact on the psychological well-being of the mothers. The purpose of this study was to determine whether parenting self-efficacy and optimism affect the psychological well-being of mothers with ID children. This study used a quantitative approach with a causal correlational design. The research subjects were 43 mothers who had children with ID. The data was collected using a questionnaire consists of the SelfEfficacy for Parenting Index (SEPTI) adapted from Coleman and Karakker, optimism scale, and psychological well-being Scales (PWBS) adapted from Ryff. The results show that parenting selfefficacy and optimism had an effect on psychological well-being.
\end{abstract}

Keywords: parenting self-efficacy, optimism, psychological well-being, intellectual disability (ID)

\begin{abstract}
Abstrak
Kehadiran setiap anak akan memengaruhi kehidupan orang tuanya. Mengasuh dan mendidik anak Intellectual Disability (ID) menimbulkan tekanan tertentu, terutama bagi ibu. Tidak sedikit ibu yang mengalami stres dan memiliki perasaan tidak yakin atas kemampuannya dalam mengasuh yang berujung pada pesimisme sehingga berdampak pada kesejahteraan psikologis ibu. Tujuan penelitian ini untuk mengetahui pengaruh parenting self-efficacy dan optimisme terhadap psychological well-being pada ibu yang memiliki anak ID. Penelitian ini menggunakan pendekatan kuantitatif dengan rancangan korelasional yang bersifat kausalitas. Subjek penelitian sebanyak 43 ibu yang memiliki anak ID. Teknik pengambilan data menggunakan kuesioner, yaitu Self-Efficacy for Parenting Index (SEPTI) yang diadaptasi dari Coleman dan Karakker, skala optimisme, dan Psychological Well-Being Scales (PWBS) yang diadaptasi dari Ryff. Hasil penelitian menunjukkan bahwa parenting self-efficacy dan optimisme berpengaruh terhadap psychological well-being.
\end{abstract}

Kata Kunci: parenting self-efficacy, optimisme, psychological well-being, intellectual disability (ID)

\section{Pendahuluan}

Setiap orang tua memiliki harapan anaknya tumbuh sehat, sempurna dan berhasil dalam kehidupannya. Orang tua juga mempunyai mimpi terhadap masa depan anak-anak mereka, seperti bisa mendapatkan prestasi di sekolah, mendapatkan sekolah terbaik dari jenjang taman kanak-kanak hingga perguruan tinggi, serta mendapatkan pekerjaan yang memiliki penghasilan tinggi. Namun pada kenyataannya ada anak yang terlahir tidak sempurna baik fisik, intelektual maupun mental, hal ini menimbulkan kesedihan yang mendalam bagi orang tua terutama ibu.

Anak dengan kondisi tersebut biasanya disebut sebagai anak berkebutuhan khusus (ABK) yang artinya adalah anak yang dianggap memiliki kelainan dari kondisi rata-rata anak normal dalam hal fisik, mental dan karakteristik perilaku sosialnya 
(Abdullah, 2013). Berdasarkan data yang diperoleh dari Badan Pusat Statistik, melalui laman Kementerian Pendidikan dan Kebudayaan (2017) jumlah ABK di Indonesia mencapai angka 1.6 juta jiwa. Menurut Undang-undang nomor 4 tahun 1997 pasal 1 ayat 1 tentang penyandang cacat dibagi ke dalam 3 kategori, yaitu: (1) cacat fisik, yang meliputi hambatan penglihatan (tunanetra), hambatan pendengaran dan berbicara (tunarungu), cacat tubuh seperti orang yang mengalami polio dan gangguan gerak (tunadaksa), (2) cacat mental, yang meliputi keterbelakangan mental (tunagrahita), mengalami gangguan emosi dan sosial (tunalaras), mengalami gangguan interaksi, komunikasi dan perilaku berulang dan terbatas (autis), (3) cacat fisik dan mental, seseorang yang mengalami dua atau lebih hambatan dalam dirinya, yang disebut sebagai tunaganda (Kementerian Kesehatan RI, 2014b).

Berdasarkan data Riset Kesehatan Dasar (Riskesdas) yang melakukan pendataan kecacatan pada anak usia 24-59 bulan pada tahun 2010 menunjukkan pada tahun 2010 anak yang mengalami tunagrahita (ID) menduduki level ketiga terbanyak (Kementerian Kesehatan RI, 2014). Latief (2015) menyatakan bahwa jumlah penyandang ID sebanyak $2 \%$ berkategori mild atau ringan, .5\% berkategori moderate atau sedang, dan .25 $\%$ berkategori profound atau berat dari penduduk dunia. Perkiraan jumlah tersebut di Indonesia adalah sebanyak $2.75 \%$ dari jumlah 280 juta penduduk, yaitu sekitar 7.7 juta penduduk Indonesia.

Intellectual disability (ID) memiliki persamaan kata dengan keterbelakangan mental, retardasi mental, mental defeciency, mental defective dan tunagrahita (Somantri, 2012). ID merupakan kelainan mental yang bersifat menetap atau akan disandang sepanjang hayatnya. Dalam DSM-V (Diagnostic and Statistical manual of Mental disorder-V), ID merupakan salah satu dari gangguan neurodevelopmental, yaitu gangguan yang terjadi selama masa perkembangan anak yang mencakup di dalamnya gangguan dalam fungsi intelektual, fungsi adaptif dalam ranah konseptual, fungsi sosial serta fungsi praktisnya. ID mempunyai 4 kategori, yaitu: mild (ringan), moderate (sedang), severe (berat), dan profound (sangat berat) (American Psychiatric Association, 2013).

Orang tua yang memiliki anak ID akan merasakan kesedihan mendalam. Kondisi anak yang sejak lahir dinyatakan berkebutuhan khusus membuat orang tua merasa kaget, kecewa, marah, merasa bersalah, dan tidak jarang menolaknya karena sulit mempercayai kondisi anak. Karena kecacatan anak mereka, orang tua menderita rasa kehilangan serta harapan, hal ini dapat membawa orang tua pada siklus penderitaan atau kesedihan yang berkepanjangan (Kore dkk., 2017). Hal tersebut memicu stres bagi orang tua khususnya ibu yang telah melahirkannya.

Stres pengasuhan biasanya berkaitan dengan tantangan dan tuntutan sehari-hari dalam memberikan perawatan bagi anakanak dengan kesulitan perkembangan yang serius seperti ID (Vilaseca dkk., 2020). Membesarkan anak ID menciptakan tantangan psikologis yang sangat besar bagi kedua orang tua seperti depresi, kecemasan, dan gejala somatik (Oti-Boadi, 2017). Orang tua menghadapi banyak emosi negatif dan juga memiliki lebih banyak ketakutan tentang masa depan anak mereka yang akan berdampak buruk pada kesejahteraan psikologis mereka. Selain itu akan timbul juga perasaan tidak percaya diri, kurang mampu mengasuh, merasa kebingungan serta adanya rasa malu yang menyebabkan orang tua menjadi tidak ingin berinteraksi dengan lingkungan sekitar (Somantri, 2012). Kondisi ini tentu akan mengganggu kesejahteraan psikologis (psychological well-being) orang tua.

Psychological well-being adalah kemampuan seseorang dalam menerima diri, membangun hubungan yang baik dan positif kepada individu lain, independen dalam keseharian, tidak mengandalkan 
orang lain, mampu menguasai lingkungan serta tidak mudah dikendalikan lingkungan, memiliki tujuan dalam kehidupannya serta mampu mewujudkan kemampuan yang ada dalam dirinya secara berkesinambungan (Ryff \& Keyes, 1995).

Psychological well-being sangat dibutuhkan ibu dalam mengasuh anaknya sehingga berdampak pada tumbuh kembang dan kebahagiaan anak. Terdapat enam dimensi psychological well-being yang bersifat multidimensional dari Ryff (1989), yaitu: self-acceptance, positive relations with others, autonomy, environmental mastery, purpose in life, dan personal growth. Dalam pengasuhan anak ID, orang tua membutuhkan keyakinan diri dalam mengasuh atau parenting selfefficacy serta memiliki sikap positif atau optimisme.

Parenting self-efficacy dapat diartikan sebagai estimasi self-referent atau bagaimana orang tua menilai diri terhadap kemampuan mereka di dalam melaksanakan peran sebagai orang tua untuk recreation atau mendukung kebutuhan anak untuk rekreasi, nurturance atau pengasuhan secara emosional, dan health atau pemeliharaan kesehatan fisik anak (Coleman \& Karraker, 2000). Parenting self-efficacy adalah keyakinan orang tua (khususnya ibu) akan kemampuannya dalam memengaruhi perilaku yang berkaitan dengan perkembangan anaknya. Ibu yang memiliki parental self-efficacy tinggi akan menyediakan lingkungan yang adaptif, menstimulasi kemampuan dan perkembangan anaknya. Contoh ibu dengan parenting self-efficacy tinggi yang memiliki anak ID diantaranya adalah memasukkan anaknya ke sekolah khusus dan ke lembaga terapi. Sedangkan ibu dengan parental self-efficacy rendah akan mengalami stres, depresi, berperilaku ingin selalu mempertahankan diri dan mengendalikan, adanya kecenderungan anak memiliki perilaku yang bermasalah, orang tua juga beranggapan anak memiliki perilaku yang menantang dan tidak mudah, serta memiliki tipe penyelesaian masalah yang pasif (Antawati \& Murdiyani, 2013).

Parental self-efficacy merupakan komponen penting bagi kesejahteraan ibu (Rosenblum-Fishman, 2013) dan orang tua yang memiliki parental self-efficacy yang tinggi lebih peka untuk menanggapi kebutuhan anak-anak mereka (Sarwar dkk., 2019). Menurut Coleman dan Karakker (2000) terdapat lima dimensi yang dapat menilai persepsi yang dimiliki orang tua khususnya ibu dalam melakukan tugastugas parenting, yaitu: discipline (disiplin), achievement (prestasi), recreation (rekreasi), nurturance (pengasuhan), dan health (kesehatan).

Hal lain yang dibutuhkan orang tua adalah sifat optimis. Optimis merupakan salah satu karakteristik positif yang dibutuhkan orang tua dalam pengasuhan anak mereka. Untuk orang tua dari anakanak dengan developmental delay, optimisme telah ditemukan secara konsisten menurunkan stres dalam pengasuhan dan meningkatkan kesejahteraan (Kurtz-Nelson \& McIntyre, 2017). Temuan ini menunjukkan bahwa optimisme berfungsi sebagai faktor pelindung bagi orang tua yang mengalami berbagai faktor risiko, termasuk keterlambatan perkembangan anak. Seligman (2006) menyatakan bahwa optimisme adalah bagaimana seseorang bersikap positif terhadap suatu keadaan, juga merupakan suatu paham yang dimiliki seseorang bahwa kegagalan hanya bersifat sementara, akan berlalu dengan cepat dan banyak hal yang bisa dilakukan dalam hidup. Tasya dan Qodariah (2018) mengutip pernyataan Seligman (2006) bahwa "Individu yang optimis akan melakukan usaha dalam mengatasi keadaan yang tidak menguntungkan bagi dirinya, berpikir bahwa keadaan buruk merupakan tantangan, tidak merasa cepat putus asa, memiliki dukungan sosial sehingga pada akhirnya akan memiliki kesehatan yang lebih baik". Menurut Seligman (2006) seseorang menjelaskan sesuatu yang 
dialami, baik itu peristiwa menyenangkan maupun tidak menyenangkan dengan menggunakan tiga dimensi, yaitu: permanence, pervasiveness, dan personalization (Arif, 2016).

Dalam penelitian Nirmala (2013) disebutkan bahwa optimisme memiliki dua faktor yaitu faktor etnosentris yang meliputi keluarga, struktur sosial, jenis kelamin, agama, kebangsaan, dan kebudayaan, serta faktor egosentris yang menjadikan diri sendiri sebagai pusat dari semua hal, melihat peristiwa yang ada dari sudut pandangnya sendiri, dimana hal tersebut menjadi pembeda cara berpikir seseorang.

Melihat penjabaran di atas, seorang ibu memiliki tugas dan tanggung jawab yang besar dalam mengasuh anak ID mereka. Ibu harus merasa yakin dengan kemampuan mengasuh dan mendidik anaknya, karena hanya ibulah yang paling memahami anak, kebiasaan dan perilakunya. Keyakinan tersebut juga perlu disertai dengan sikap positif yaitu optimis dalam memandang masa depan sehingga hal tersebut dapat mengurangi perasaan tidak berdaya, stress, dan permasalahan psikologis lainnya yang akhirnya dapat membantu ibu untuk meningkatkan kesejahteraan psikologis mereka.

Penelitian ini memiliki tujuan untuk mengetahui bagaimana parenting selfefficacy yang dimiliki ibu dari anak ID serta bagaimana optimisme mereka dapat memengaruhi kesejahteraan psikologisnya.

\section{Metode Penelitian}

Penelitian ini menggunakan pendekatan kuantitatif, jenis korelasional kausalitas yang bersifat prediktif, dimana dua variabel prediktor diprediksi memengaruhi terjadinya variabel kriteria. Adapun variabel-variabel tersebut adalah: parenting self- efficacy sebagai variabel prediktif 1 (X1), optimisme sebagai variabel prediktif 2 (X2), dan psychological well-being sebagai variabel kriteria $(\mathrm{Y})$.

\section{Subjek Penelitian}

Subjek dalam penelitian ini adalah ibu yang memiliki anak ID yang berada pada usia sekolah atau anak berada pada rentang usia 5-12 tahun (rentang usia ini digunakan berdasarkan alat ukur self-efficacy for parenting tasks index), dan ibu yang memiliki latar belakang pendidikan minimal SMA atau sederajat, karena tingkat pendidikan ibu merupakan salah satu faktor yang memengaruhi parenting self-efficacy dan tingkat pendidikan ibu sangat berpengaruh pada perkembangan anak (Ariani \& Yosoprawoto, 2012). Berdasarkan survei yang telah dilakukan ke 5 sekolah luar biasa (SLB) yang berada di beberapa daerah di kota Bandung yaitu: 1 SLB di Ujung Berung, 1 SLB di Batununggal dan 3 SLB di Kiaracondong, kelima SLB tersebut dipilih karena memiliki jumlah murid cukup banyak. Dari 5 SLB tersebut terdapat 43 orang ibu yang masuk ke dalam kategori di atas dan dijadikan subjek penelitian ini.

\section{Instrumen Penelitian}

Penelitian ini menggunakan instrumen pengumpulan data berupa skala likert. Terdapat 4 alternatif jawaban pada setiap skala, yaitu: SS (sangat sesuai), S (sesuai), TS (tidak sesuai) dan STS (sangat tidak sesuai).

\section{Skala Parenting Self-Efficacy}

Skala parenting self-efficacy pada penelitian ini menggunakan kuesioner SelfEfficacy for Parenting Index (SEPTI) dari Coleman dan Karakker (2000). Skala ini terdiri dari 36 item (28 item terpakai dan 8 item tidak terpakai) yang tersusun dari 5 dimensi yaitu: (1) discipline, achievement, (3) recreation, (4) nurturance, dan (5) health. Contoh item pada alat ukur ini adalah: "Saya selalu memastikan bahwa anak saya menerima perawatan medis yang tepat sesuai kebutuhan". Hasil uji validitas pada setiap dimensi diperoleh rentang .657 sampai dengan 833 (tinggi hingga sangat tinggi). Sedangkan koefisien reliabilitas sebesar .843 (sangat tinggi). 


\section{Skala Optimisme}

Skala optimisme yang digunakan dalam penelitian ini memodifikasi skala yang dimuat pada skripsi Nirmala (2013), yang mengacu pada alat ukur optimisme dari Seligman (2006). Skala ini terdiri dari 42 item (34 item terpakai dan 8 item tidak terpakai) yang tersusun dari 3 dimensi yaitu: (1) permanence, (2) pervasiveness, dan (3) personalization. Contoh item pada alat ukur ini adalah: "Saya percaya setiap masalah yang datang pasti ada jalan keluarnya". Hasil uji validitas untuk setiap dimensi diperoleh rentang nilai .894 sampai dengan .927 (sangat tinggi). Demikian pula koefisien reliabilitas yang diperoleh sebesar .879 (sangat tinggi).

\section{Skala Psychological Well-Being}

Skala psychological well-being pada penelitian ini mengadaptasi Psychological Well Being Scales (PWBS) dari Ryff (1989, 1995). Skala ini terdiri dari 42 item (31 item terpakai dan 11 item tidak terpakai) yang tersusun dari 6 dimensi yaitu: (1) autonomy, (2) environmental mastery, (3) personal growth, (4) positive relations with other, (5) purpose in life, dan (6) selfacceptance. Contoh item dari skala PWB adalah "Kebanyakan orang melihat saya sebagai orang yang penuh cinta dan kasih sayang" dan "Keputusan-keputusan yang saya ambil tidak dipengaruhi oleh orang lain". Uji validitas pada dimensi-dimensi PWB diperoleh nilai pada rentang .584 sampai dengan .819. Ini menunjukkan kriteria sedang, tinggi dan sangat tinggi. Khusus untuk dimensi personal growth memiliki validitas sedang. Sedangkan koefisien reliabilitas yang diperoleh sebesar .875 (sangat tinggi).

\section{Teknik Analisis Data}

Penelitian ini memakai teknik analisis regresi berganda, karena pada dasarnya penelitian ini ingin mengetahui pengaruh dari dua variabel prediktif, yaitu parenting self-efficacy dan optimisme terhadap satu variabel kriteria, yaitu psychological wellbeing. Adapun langkah-langkah untuk melakukan analisis regresi berganda yaitu dengan melakukan uji asumsi klasik yang terdiri dari uji normalitas, uji multikolinieritas, uji heterosedastisitas, dan uji autokorelasi.

Setelah uji asumsi klasik dan data dinyatakan memenuhi syarat untuk dilakukan persamaan regresi, maka langkah selanjutnya analisis regresi linier berganda untuk menyusun model regresinya, dilanjutkan dengan uji koefisien determinasi, uji simultan (uji F), dan uji pasrsial (uji t).

\section{Hasil Penelitian dan Pembahasan}

Berdasarkan pengolahan data didapatkan hasil bahwa nilai median dari variabel parenting self-efficacy sebesar 87, optimisme sebesar 108.00 dan psychological well-being sebesar 91.00. Dari hasil tersebut peneliti membagi ke dalam dua kategori untuk variabel parenting self-efficacy yaitu tinggi dan rendah. Kategori tinggi apabila skor yang diperoleh subjek lebih besar atau sama dengan nilai median, dan kategori rendah jika subjek memperoleh skor di bawah nilai median. Hasil kategorisasi dapat dilihat pada tabel 1 sampai dengan tabel 3 .

Tabel 1

Kategori Variabel Parenting Self-Efficacy

\begin{tabular}{lcc}
\hline \multicolumn{1}{c}{ Kategori } & Jumlah & Persentase \\
\hline Tinggi & 22 & $51.16 \%$ \\
Rendah & 21 & $48.84 \%$ \\
Jumlah & 43 & $100 \%$ \\
\hline
\end{tabular}

Tabel 2

Kategori Variabel Optimisme

\begin{tabular}{lcc}
\hline \multicolumn{1}{c}{ Kategori } & Jumlah & Persentase \\
\hline Tinggi & 24 & $55.81 \%$ \\
Rendah & 19 & $44.19 \%$ \\
Jumlah & 43 & $100 \%$ \\
\hline
\end{tabular}


Tabel 3

Kategori Variabel Psychological Well-Being

\begin{tabular}{lcc}
\hline \multicolumn{1}{c}{ Kategori } & Jumlah & Persentase \\
\hline Tinggi & 23 & $53.49 \%$ \\
Rendah & 20 & $46.51 \%$ \\
Jumlah & 43 & $100 \%$ \\
\hline
\end{tabular}

Hasil analisis data menunjukkan bahwa data dalam penelitian ini berdistribusi normal berdasarkan hasil uji KolmogorovSmirnov yaitu nilai $p$-value sebesar $.200>$ .05 mengizinkan penggunaan analisis regresi klasik. Selanjutnya dilakukan beberapa pengujian yang diperlukan pada analisis regresi linier berganda. Pertama, tidak terjadi multikolinieritas berdasarkan hasil VIF yaitu $1.617>10$. Selanjutnya, tidak terjadi heteroskedastisitas berdasarkan hasil uji t dengan signifikansi semuanya di atas .05. Terakhir, juga tidak terjadi autokorelasi berdasarkan hasil uji Durbin Watson yaitu 1.768 dimana nilai ini berada dalam rentang yang menandakan tidak adanya autokorelasi yaitu DU < DW < 4 DU atau $1.55773<1.768<2.44227$. Hasilhasil tersebut menunjukkan bahwa model yang dipilih sudah baik dan representatif serta sesuai dengan penggunaan metode estimasi menggunakan Metode Kuadrat Terkecil.

Hasil analisis data untuk uji model juga dilakukan dengan uji simultan yang menggunakan uji $\mathrm{F}$ dan uji parsial dengan uji t. Diperoleh hasil Fhitung sebesar 23.522 dengan nilai signifikansi sebesar $.000<.05$ yang berarti $\mathrm{H} 0$ ditolak, sehingga parenting self-efficacy dan optimisme secara bersama-sama berpengaruh terhadap psychological well-being. Untuk uji parsial dengan uji $t$ memberikan hasil nilai koefisien regresi $\mathrm{X} 1$ (parenting selfefficacy) adalah sebesar .316 dan X2 (optimisme) sebesar .497, keduanya bernilai positif, sehingga dapat dikatakan bahwa parenting self-efficacy dan optimisme berpengaruh positif terhadap psychological well-being. Pengaruh positif diartikan bahwa semakin meningkat parenting self- efficacy dan optimisme, maka akan meningkat pula psychological well-being.

Terakhir, uji model dengan koefisien determinasi (R-square). Berdasarkan hasil perhitungan didapatkan nilai koefisien determinasi sebesar .540, artinya psychological well- being dipengaruhi oleh variabel parenting self-efficacy dan optimisme sebesar 54\%, sedangkan sisanya sebesar $46 \%$ dipengaruhi oleh faktor lain yang tidak diteliti dalam penelitian ini.

Hasil perhitungan di atas juga menunjukkan bahwa nilai signifikansi untuk variabel parenting self-efficacy adalah $.038<.05$, artinya parenting selfefficacy berpengaruh secara parsial terhadap psychological well-being. Nilai signifikansi untuk variabel optimisme adalah . $000<.05$, artinya optimisme berpengaruh secara parsial terhadap psychological well-being.

Hasil analisis data memberikan juga estimasi terhadap koefisien-koefisien regresi yang berguna untuk menyusun model regresi. Diperoleh persamaan regresi linier berganda sebagai berikut:

$$
\hat{Y}=10.501+.316 \mathrm{X} 1+.497 \mathrm{X} 2
$$

Dari hasil analisis data diketahui bahwa terdapat pengaruh secara simultan parenting self-efficacy dan optimisme ibu terhadap psychological well-being. Secara parsial parenting self-efficacy juga berpengaruh terhadap psychological well being. Optimisme juga terbukti secara parsial berpengaruh pada psychological well being.

\section{Pembahasan}

Kehadiran anak ID di tengah-tengah keluarga, sangat memengaruhi suasana keluarga. Banyak sekali tantangan dalam perawatan dan pengasuhan anak ID. Tentu saja ini berdampak pada seluruh anggota keluarga, seperti orang tua, saudara kandung, kakek, nenek dan keluarga lainnya. Adanya stigma, prasangka yang dilabelkan kepada anak tersebut, serta hambatan yang membatasi hak asasi 
mereka. Stigma yang dikonseptuali-sasikan sebagai tanda aib sosial (Mitter dkk., 2018). Hal tersebut membuat keluarga seringkali mendapatkan perlakuan yang tidak adil dari lingkungan seperti bully, cibiran dan prasangka yang menyatakan kehadiran anak tersebut karena kesalahan orang tua di masa lalu. Ini membuat orang tua merasa sedih dan malu. Selain hambatan dari lingkungan, orang tua juga merasa kesulitan dalam mengasuh dan mendidik anak ID karena kemungkinan adanya permasalahan kesehatan, permasalahan perilaku serta sosial emosi. Apalagi menurut Emerson dkk. (2008) anak ID sebagian besar tinggal di rumah bersama orang tua mereka, dengan mayoritas orang tua memberikan dukungan seumur hidup kepada anak mereka (Beighton dkk., 2017).

Anak ID memiliki tingkat keparahan yang berbeda, hal ini bisa dilihat dari kategorinya. Anak ID yang memiliki kategori ringan (mild) cenderung memiliki kompleksitas gejala lebih sedikit dibandingkan dengan anak ID yang sangat berat (profound). Hal ini akan memengaruhi bagaimana ibu mengasuh dan mendidik. Anak dengan kategori ID sangat berat (profound) membutuhkan pertolongan, pengawasan dan ketergantungan pada orang lain lebih tinggi dibandingkan anak ID dengan kategori ringan (mild). Namun walaupun perbedaan kategori dari ringan hingga sangat berat, tetap saja mengasuh dan mendidik anak ID bukan hal yang mudah dan menimbulkan stres yang mungkin berkepanjangan. Orang tua seringkali merasa bersalah kepada diri mereka karena merasa menjadi penyebab anak mereka menjadi cacat.

Rentang stres diantara orang tua anak ID berbeda satu dengan lainnya. Beberapa orang tua menunjukkan toleransi yang lebih baik terhadap stressor daripada yang lain, ini mungkin karena faktor-faktor tertentu seperti adanya harapan, efikasi diri, dukungan sosial, rasa koherensi, harga diri, resiliensi, optimisme, dan internal locus of control (Kore \& Venkatraman, 2017).
Efikasi diri (self efficacy) menurut Bandura (1989) merupakan keyakinan orang tentang kemampuan mereka untuk melakukan kontrol atas peristiwa yang memengaruhi kehidupan mereka (Rosenblum-Fishman, 2013). Parenting self efficacy diartikan Ardelt dan Eccles (2001) sebagai keyakinan orang tua tentang kompetensi mereka untuk mengatur lingkungan anak mereka sedemikian rupa sehingga membantu perkembangan positif agar menjadi sukses dalam menjalani kehidupan (Sarwar dkk., 2019). Keyakinan akan kemampuan diri dalam pengasuhan sangat penting. Seorang ibu dengan parenting self-efficacy yang tinggi akan berusaha mengarahkan dirinya untuk menyediakan lingkungan yang adaptif dan mencari strategi agar anaknya dapat tumbuh dan berkembang lebih optimal. Ia akan berusaha sekuat tenaga, tidak mudah stres dan menyerah bila mengalami suatu kesulitan, ia memiliki kepercayaan diri serta memiliki resiliensi yang baik. Rasa percaya diri dapat meningkatkan resiliensi pada orang tua ketika memiliki anak berkebutuhan khusus (Pranandita \& Ayriza, 2018). Selain itu parenting self-efficacy berhubungan dengan pengasuhan yang positif (Coleman dan Karraker, 2000).

Seorang ibu dengan parenting selfefficacy yang rendah, lebih cenderung menjadi kewalahan ketika menghadapi banyak stressor, mereka cenderung menyerah untuk terlibat dalam tindakan positif (Young, 2011). Padahal parenting self-efficacy merupakan komponen penting bagi kesejahteraan ibu (RosenblumFishman \& Sara, 2013). Artinya parenting self-efficacy berpengaruh terhadap kesejahteraan psikologis ibu. Ibu yang memiliki psychological well being tinggi akan berdampak pada kebahagiaan dan kesejahteraan psikologis anaknya yang ID serta lingkungan keluarganya. Ia mampu menjalani hidupnya dengan lebih baik dan terhindar dari stres.

Menurut Coleman dan Karakker (2000) terdapat lima dimensi yang dapat menilai 
persepsi yang dimiliki oleh orang tua khususnya ibu dalam melakukan tugastugas pengasuhan, yaitu: Pertama, menegakkan discipline (disiplin). Dalam mengasuh dan mendidik anak, ibu harus memiliki aturan yang telah disesuaikan dengan tahapan perkembangan anak. Aturan ini membantu anak bertanggung jawab terhadap diri dan lingkungannya. Ibu harus mampu menerapkan aturan yang konsisten, ramah dan menghindari kekerasan. Kedua, achievement (prestasi) yaitu memfasilitasi anak untuk dapat berkembang dan berprestasi di sekolah dengan cara menstimulasi anak, memberikan kesempatan mereka untuk mengembangkan dirinya, memfasilitasi kebutuhan anak dan membantu mengembangkan kreativitas anak.

Ketiga, recreation (rekreasi). Ibu harus memperhatikan dan memenuhi kebutuhan anak untuk dapat bermain dan berinteraksi dengan teman sebaya serta memberikan kesempatan dan memfasilitasi agar dapat berekreasi. Keempat, nurturance (pengasuhan) yaitu memenuhi kebutuhan emosional anak. Dalam hal ini ibu harus peka terhadap kebutuhan emosi anak, dapat memberikan rasa nyaman, perhatian, membantu anak untuk dapat mengekspresikan pemikiran dan perasaannya. Kelima, health (kesehatan) yaitu ibu harus memperhatikan kesehatan anak dengan memberikan gizi yang baik, mengajarkan kebersihan, kesehatan dan hidup sehat kepada anak.

Kelima hal tersebut di atas merupakan hal yang perlu ibu miliki dalam pengasuhan anak ID. Adanya aturan yang diterapkan secara konsisten dapat membantu anak untuk mengetahui apa yang dituntut lingkungan terhadap dirinya, sehingga ia bisa mengikuti aturan tersebut dan dapat mengelola emosi mereka karena mereka mengetahui batasan apa yang boleh dan tidak boleh dilakukan. Aturan dan rutinitas juga membantu mereka memprediksi kegiatan yang akan dilakukan pada saat itu dan yang akan datang. Begitu pula dengan dimensi lainnya yang saling mendukung dan melengkapi sehingga anak dapat berkembang optimal sesuai dengan potensi yang dimiliki.

Hal lainnya yang dapat membuat ibu memiliki toleransi yang baik terhadap stressor yaitu optimis. Ibu yang memiliki optimisme cenderung memiliki harapan untuk mencapai tujuan yang ia targetkan. Ia tidak mudah berputus asa, menganggap kegagalan yang dihadapi merupakan suatu hal yang biasa, karena ia beranggapan bahwa kegagalan sifatnya sementara. Begitu pula ketika ia mendidik anaknya yang ID, maka ia akan terus mencoba dan berpikir positif akan kemampuan anaknya. Ia memiliki suatu keyakinan yang kuat akan suatu keberhasilan di kemudian hari. Optimisme adalah sifat individu untuk mengharapkan hasil yang baik dari peristiwa yang terjadi dalam hidup dan optimisme akan mengarah pada kesehatan psikologis dan fisik yang positif (Sarwar dkk., 2019).

Tingkat optimisme yang dimiliki orang tua (ibu) dapat memengaruhi bagaimana mereka berpikir dan merasa tentang anakanak mereka yang mengalami keterlambatan perkembangan (KurtzNelson \& McIntyre, 2017). Ibu yang optimis, akan memiliki pikiran positif, dan hal ini akan berpengaruh terhadap apa yang ia rasakan dan respon perilaku yang mereka tampilkan. Sikap optimis juga memengaruhi cara pandang dan daya resiliensi (ketahanan) ibu. Optimisme dapat meningkatkan ketahanan terhadap stres pada orang tua, digambarkan sebagai sifat pribadi, dan merupakan suatu harapan, bahwa hasil positif akan terjadi (Damgård dkk., 2016). Ibu yang memiliki optimisme tidak mudah stres dan memiliki emosi negatif dan hal ini berdampak pada psychological well being dirinya.

Menurut Seligman (2006) seseorang menjelaskan sesuatu yang dialami baik menyenangkan maupun tidak menyenangkan dengan menggunakan tiga dimensi, yaitu: Pertama, permanence 
(permanen lawan sementara). Aspek ini berkaitan dengan waktu. Seorang yang pesimis akan memandang kejadian yang tidak menyenangkan akan terus terulang, tidak dapat ia kendalikan, dan memandang kejadian yang menyenangkan itu sebagai sesuatu yang datangnya hanya sementara, tidak akan terulang lagi dan berpikir bahwa kejadian tersebut hanya keberuntungan atau kebetulan. Sedangkan seorang yang optimis, ia akan memandang kejadian tidak menyenangkan itu hanya sementara dan ia dapat mengendalikan atau mencegah terjadinya kejadian serupa, dan memandang kejadian yang menyenangkan itu sebagai sesuatu yang permanen atau akan terus berulang, bukan kebetulan melainkan bisa diusahakan agar terjadi kembali.

Kedua, pervasiveness (spesifik lawan universal). Aspek ini berkaitan dengan dimensi ruang lingkup, bagaimana seseorang menyikapi kejadian yang dialami, baik menyenangkan maupun tidak menyenangkan, apakah kejadian yang terjadi itu menggambarkan keseluruhan dirinya dan berdampak bagi area kehidupan yang lain atau tidak. Seorang yang pesimis akan memandang kejadian yang tidak menyenangkan merupakan gambaran keseluruhan dirinya yang buruk dan akan berdampak pada area kehidupannya yang lain, dan memandang kejadian yang menyenangkan merupakan gambaran sementara saja atau gambaran satu sisi dirinya saja dan area kehidupannya yang lain tetap buruk. Berbeda halnya dengan seorang yang optimis, ia akan memandang suatu kejadian yang tidak menyenangkan merupakan gambaran satu sisi dirinya dan tidak ada kaitannya dengan area kehidupannya yang lain, dan memandang kejadian menyenangkan merupakan gambaran keseluruhan dirinya yang baik dan akan berdampak pada area kehidupannya yang lain.

Ketiga, personalization (internal lawan eksternal). Aspek ini mengacu pada penyebab suatu kejadian itu terjadi, baik menyenangkan maupun tidak menyenang- kan, dengan munculnya pertanyaan apakah kejadian yang terjadi itu disebabkan oleh diri sendiri (internal) ataukah disebabkan oleh hal-hal di luar diri (eksternal). Seorang yang pesimis akan memandang kejadian yang tidak menyenangkan itu utamanya disebabkan oleh dirinya sendiri dan ia akan menghakimi dan menyalahkan dirinya atas kejadian tersebut, dan memandang kejadian yang menyenangkan itu utamaya disebabkan oleh faktor-faktor di luar dirinya yang mana ia tidak memiliki kendali atasnya. Seorang yang optimis akan memandang kejadian tidak menyenangkan utamanya disebabkan oleh faktor-faktor di luar dirinya dan ia dapat melakukan banyak hal untuk memperbaikinya, dan memandang kejadian menyenangkan utamanya disebabkan oleh dirinya sendiri, merupakan pilihan, tindakan dan ketekunan dirinya sendiri (Arif, 2016).

Perbedaan sudut pandang antara seorang yang optimis dan pesimis sangat memengaruhi sikap dan respon mereka terhadap peristiwa yang mereka hadapi dan hal tersebut berdampak pada kesejahteraan psikologisnya. Seorang ibu yang merasa yakin akan kompetensinya dalam mengasuh anak mereka yang disabilitas serta memiliki karaktersitik sifat optimis, akan memperkuat ibu dalam mengatasi tantangan yang akan dihadapi dalam kehidupannya sehari-hari.

Perbedaan antara penelitian ini dan penelitian sebelumnya adalah melihat peran ibu sebagai sosok pengasuh, orang yang terdekat dengan anak, dimana stres ibu pada umumnya lebih tinggi serta bagaimana keyakinan akan kompetensinya dan bagaimana pandangan serta rasa optimisnya ketika memberikan pengasuhan kepada anak ID mereka dengan segala tantangan yang ditemui dalam keseharian yang berdampak pada kesejahteraan dirinya.

Keterbatasan dalam penelitian ini berkaitan dengan jumlah sampel yang sesuai karakteristik masih terbatas, meskipun diambil dari lima sekolah luar biasa di kota Bandung. Diharapkan 
penelitian selanjutnya dapat menambah jumlah sampel penelitian dengan menambah sekolah luar biasa.

\section{Simpulan}

Penelitian ini bertujuan untuk mengetahui apakah parenting self efficacy dan optimisme berpengaruh atau tidak terhadap psychological well being pada ibu yang memiliki anak dengan intellectual disability. Hasil penelitian memperlihatkan adanya pengaruh secara simultan parenting self-efficacy dan optimisme terhadap psychological well being pada ibu yang memiliki anak ID. Semakin tinggi parental self-efficacy dan optimisme akan membuat ibu semakin merasa sejahtera secara psikologis (psychological well being). Semakin rendah parenting self efficacy dan optimisme maka ibu kurang sejahtera secara psikologis serta rentan mengalami stres dan depresi.

\section{Daftar Pustaka}

Abdullah, N. (2013). Mengenal anak berkebutuhan khusus. Magistra, 86, 110.

American Psychiatric Association. (2013). Diagnostic and statistical manual of mental disorders $\left(5^{\text {th }} e d.\right)$. American Psychiatric Publishing.

Antawati D. I., \& Murdiyani H. (2013). Dinamika psikologis pembentukan parenting self-efficacy pada orang tua penyandang tunarungu yang memiliki anak berpendengaran normal. Jurnal Psikologi Teori dan Terapan, 4(1), 3147.

http://dx.doi.org/10.26740/jptt.v4n1.p3 $1-47$

Ardelt, M., \& Eccles, J. S. (2001). Effects of mother's parental efficacy beliefs and promotive parenting strategies on inner-coty youth. Journal of Family Issues $\quad 22(8), \quad 944-972$. https://doi.org/10.1177/0192513010220 08001

Ariani, \& Yosoprawoto, M. (2012). Usia anak dan pendidikan ibu sebagai faktor risiko gangguan perkembangan anak. Jurnal Kedokteran Brawijaya, 27(2), 118-121.

http://dx.doi.org/10.21776/ub.jkb.2012. 027.02 .13

Arif, I. S. (2016). Psikologi positif. PT. Gramedia Pustaka Utama.

Beighton, C., \& Jane, W. (2017). Are parents identifying positive aspects to parenting their child with an intellectual disability or are they just coping? A qualitative exploration. Jurnal of Intellectual Disabillity, 21(4), 325-345.

https://doi.org/10.1177/1744629516656 $\underline{073}$

Oti-Boadi, M. (2017), Exploring the lived experiences of mothers of children with intellectual disability in Ghana.

SAGE

Open. https://doi.org/10.1177/2158244017745 578

Coleman, P. K., \& Karraker, K. H. (1998). Self-efficacy and parenting quality: Findings and future applications. Developmental Review, 18(1), 47-85. https://doi.org/10.1006/drev.1997.0448

Coleman, P. K., \& Karraker, K. H. (2000). Parenting self-efficacy among mothers of school-age children: Conceptualization, measurement, and correlates. Family Relations: An Interdisciplinary Journal of Applied Family Studies, 49(1), 13-24. https://doi.org/10.1111/j.17413729.2000.00013.x

Emerson, E., Graham, H., McCulloch, A., Blacher, J., Hatton, C., \& Llewellyn, G. (2008). The social context of parenting 3 year old children with development delay in the UK. Child: care, health and development, 35(1), 63-70. https://doi.org/10.1111/j.13652214.2008.00909.x

Ghoniyah, \& Savira. (2015). Gambaran psychological well-being pada perempuan yang memiliki anak down 
syndrome. Character: Jurnal Penelitian Psikologi, 3(3), 1-8.

Kementerian Kesehatan Republik Indonesia. (2014 ). Penyandang disabilitas pada anak. https://www.kemkes.go.id/article/view/ 15021800008/penyandang-disabilitaspada-anak.html

Kementerian Kesehatan RI. (2014b). Situasi penyandang disabilitas. Buletin Jendela Data \& Informasi Kesehatan, Semester2(1), 1-5. https://doi.org/10.1007/s13398-0140173-7.2

Keyes, C. L. M., Shmotkin, D., \& Ryff, C.

D. (2002). Optimizing well-being: The empirical encounter of two traditions. Journal of Personality and Social Psychology, 82(6), 10071022. https://doi.org/10.1037/00223514.82.6.1007

Kore, R., \& Venkatraman, S. (2017). A study on hope, stress and self-efficacy in parents of children with intellectual disability. Indian Journal of Mental Health, 4(3), 243-251. http://dx.doi.org/10.30877/IJMH.4.3.20 17.243-251

Kurtz-Nelson E., \& McIntyre, L. L. (2017). Optimism and positive and negative feelings in parents of young children with developmental delay. $J$ Intellect Disabil Res, 61(7), 719-725. https://doi.org/10.1111/jir.12378

Latief, A. (2015, September 4). Penyandang disabilitas intelektual masuh butuh uluran tangan. Kompas. https://edukasi.kompas.com/read/2015/ 09/04/21435591/penyandangdisabilitas-intelektual-masih-butuhuluran-tangan

Mitter, N., Ali, A., \& Scior, K. (2018). Stigma experienced by family members of people with intellectual and developmental disabilities: Multidimensional construct. BJPsych, 4(5), 332-338. https://doi.org/10.1192/bjo.2018.39

Nirmala, A. P. (2013). Tingkat kebermaknaan hidup dan optimisme pada ibu yang mempunyai anak berkebutuhan khusus, 2(2), 6-12.

Pranandita P., \& Ayriza, S. Y. (2018). The relationship of parenting self-efficacy as a predictor of resilience to parents of children with special needs in inclusive schools. Advances in Social Science, Proceedings of the International Conference on Special and Inclusive Education (ICSIE 2018). https://doi.org/10.2991/icsie-18.2019.6

Damgård, R., Sørensen, K., Vestrheim, I. E., Lerdal, B., Skranes, J., \& Rohde, G., (2016). Optimism and sense of coherence in mothers and fathers of children with cerebral palsy participating in an intensified habilitation programme. Scandinavian Journal of Disability Research, 18(3), 245-255.

http://doi.org/10.1080/15017419.2015. 1064025

Ryff, C. D. (1989). Happiness is everything, or is it? Exploration on the meaning of psychological well-being. Journal of Personality and Social Psychology, 57(6), 1069-1081. https://doi.org/10.1111/14678721.ep10772395

Ryff, C. D. (1995). Psychological wellbeing in adult life. Current Directions in Psychological Science, 4(4), 99-104. https://doi.org/10.1111/14678721.ep10772395

Ryff, C. D., \& Keyes, C. L. M. (1995). The structure of psychological well-being revisited. Journal of Personality and Social Psychology, 69(4), 719-727. https://doi.org/10.1037/00223514.69.4.719

Rosenblum-Fishman, S. D. (2013). Maternal self-efficacy and perceived stigma

among mothers of children with ASD, $A D H D$, and typically developing children (Dissertation unpublished). University of Massachusetts Boston.

Sarwar, F., Panatik, S. A., Rajab, A., \& 
Nordin, N. (2019). Social support, optimism, parental self-efficacy and wellbeing in mothers of children with autism spectrum disorder. Indian Journal of Public Health Research \& Development, 10(9), 1824-1829. http://dx.doi.org/10.5958/09765506.2019 .02719 .0

Seligman. (2006). Learned optimism: How to change your mind and your life. A Division of Random House.

Somantri, S. (2012). Psikologi anak luar biasa. Refika Aditama.

Tasya, D. M. P., \& Qodariah, S. (2018). Hubungan adversity quotient dengan optimisme pada ibu yang memiliki anak down syndrome di Yayasan POTADS Bandung. Prosiding Psikologi, 4(1), 365-371. http://dx.doi.org/10.29313/.v0i0.9449

Weinstein, N. D. (1980). Unrealistic optimism about future life events. Journal of Personality and Social Psychology, 39(5), 806-820. https://doi.org/10.1037/00223514.39.5.806

Vilaseca, R., Rivero, M., Ferrer, F., \& Bersabe, R. M. (2020). Parenting behaviors of mothers and fathers of young children with intellectual disability evaluated in a natural context. PLoS One, 15(10), e0240320. https://doi.org/10.1371/journal.pone.02 40320

Young S. L. (2011). Exploring the relationship between parental selfefficacy and social support systems (Thesis tidak diterbitkan). Iowa State University. https://doi.org/10.31274/etd-1808102457 